\title{
HIGHER EDUCATION, QUALITY OF HIGHER EDUCATION, EXPERT SUPPORT AND ITS ASSURANCE: THE CANONIZATION OF CONCEPTS (THEORETICAL AND METHODOLOGICAL DISCOURSE)
}

\author{
Nina Batechko \\ ORCID iD 0000-0002-3772-4489 \\ Doctor of Pedagogical Sciences \\ Associate Professor \\ Head of Scientific-Research Laboratory of Educology \\ Borys Grinchenko Kyiv University 13-b Tymoshenko \\ Str., 04212 Kyiv, Ukraine \\ n.batechka@kubg.edu.ua
}

\begin{abstract}
The article highlights the peculiarities of the justification of the concept of "quality of education" in modern scientific discourse. At the same time, the investigated phenomenon is presented in the interpretation of the systemic and synergistic approaches. It is noted that the synergy of systematic and synergistic approaches can serve as a theoretical and methodological justification for the quality of education. In the context of systemic and synergetic approaches, modern realities of introducing the basic principles of the quality of education and its expert support in the national higher school are analysed. It has been proved that taking into account the best European principles for ensuring the quality of education and own vision of the solution of the problem will allow accelerating the processes of reforming the education sector in Ukraine.
\end{abstract}

Key words: quality of education; system approach; synergistic approach.

\section{INTRODUCTION}

In the conditions of the civilizational paradigm of the sustainable development of modern society, the centre of which is education, the quality of education becomes an indispensable attribute of improving the entire educational sphere. The latter requires a revision of the quality of education: at the national, regional and international levels.. It is also important to understand the phenomenon of the quality of education in modern scientific discourse: to clarify its methodological significance both for the process of scientific cognition and for solving a significant range of practical problems, in particular, expert support for the quality assurance of education in the educational sphere. In this aspect, it is worthwhile to study and gradually introduce in Ukraine the general criteria and basic principles for ensuring the quality of education, the forms of its monitoring, characteristic of the whole European educational space, to study in detail the international experience in introducing the quality of university education and its expert support.

The modern scientific discourse of the quality of education presupposes a variety and multi-vectorality in the interpretation of this phenomenon, however, in our opinion, the solution of all the pressing problems of education requires the 
accelerated development of a new philosophical and methodological paradigm of the quality of education and the formation on this basis of a practical worldview of all stakeholders in this field.

The purpose of the article is to analyse the quality of education, its expert support in modern scientific discourse and the methodological substantiation of the phenomenon under study in the context of synergies of general scientific approaches.

\section{ANALYSIS OF RELEVANT RESEARCHES AND PUBLICATIONS}

In a broad sense, the quality of education is studied as a complex concept within the Qualitology - the triune science, encompassing the teory of quality (Quality System), the theory of assessment of quality (qualimetry - Assessment Evaluation), the theory of quality management (Management and Monitoring of Quality). Each of these components has a certain set of criteria and indicators of the quality of education, which make it possible to evaluate variously any educational system, both by external and internal parameters (Lukina, 2008, p. 1017-1018).

Most researchers in modern scientific discourse tend to believe that the quality of education is a generalized sign of the development of education in the state as a whole, but at the same time it is an indicator of the conformity of educational policy and education reforms to personal and social needs (L. S. Vashchenko, T.O. Lukina, O. I. Leshchenko, P. B. Polenskyi and others). Nowadays the quality problems are also associated with the development of a new information civilization, where the advance development of a quality environment for people, social intelligence and the education system becomes the decisive factor in the progress of mankind (O. I. Subetto).

Some researchers explain quality as a combination of properties and characteristics of the educational process itself (K. Isinova, I. Ye. Bulakh). At the same time the following scientists: Yu. Doroshenko, N. N. Potashnyk, P. A. Romayenko, V. A. Traynov and others consider the quality of education by the final result of the procedural aspect of education and the set of graduates' competencies - a certain level of their knowledge and skills in mental, physical and moral development achieved by those who are taught at a certain stage in accordance with planned goals; the degree of satisfaction of the hopes of various participants in the process from the educational services provided by educational institutions.

Our scientific research shows that the notion of the "quality of higher education" is rarely separated by scientists from the quality of education as a whole and is interpreted basically in the same plane: the set of properties and characteristics of educational services for the comprehensive development of the student (N. O. Shmyrova), the level of the person's knowledge, skills and other competencies, reflecting his or her competence in accordance with higher education standards (the Law of Ukraine "On Higher Education”, 2014, Article 1), as a multidimensional concept, the types of activity of the higher educational institution are education, academic, academic programs, educational programs, scientific research, the academic environment of the educational institution, the educational and material base and resources (D. Stepanenko). 
The analysis of the scientific literature regarding the notions of "quality of education" and "quality of higher education" allows us to state that it differs widely in interpretation among different authors, it is used freely in an inappropriate context, which creates a "chaos of definitions" (Shchogoleva, 2014, p. 36).

Incomplete comprehension of the concept of the quality of education in the international context in a certain way stipulates, in our opinion, the lag in the Ukrainian education on the implementation of the advanced principles that characterize the European and, in general, the universal educational space, in particular, questions relating to the quality management in higher education. One explanation for this fact may be that the process of reforming the national higher school is hampered by the use of obsolete management methods by educational institutions, insufficient use of organizational innovations and progressive forms of management based on the principles of TQM (Volkov, and others, 2008, p. 4).

It is worth noting that the urgency in modern scientific discourse acquires the problems of creating special structural units that would be engaged in developing criteria, methodology and technology for assessing the quality of higher education. As M. V. Mykhaylychenko and L. Makodzey admit, in Western practice, there is the European Association for Quality Assurance in Higher Education, founded in 2000 (Mykhaylichenko, \& Makodzey, 2014). For the Ukrainian society, the existence of such a body became possible after the adoption of the Laws of Ukraine "On Higher Education" (2014) and "On Education" (2017), which indicate that the system of higher education quality of educational activities and the quality of higher education is assessed by the National Agency for Security quality of higher education.

In the context of globalization, European integration and the informatization of the society, education is becoming one of the key tools for the formation of human capital, and therefore, as I. I. Trygub notes, for the holistic study of socially significant problems in the development of the education sector in Ukraine, the training of specialists capable of expert-advisory activity in the field of education is of great importance (Trygub, 2014, p. 218).

In view of the foregoing, we consider it particularly relevant to study the quality of education and its expert support for the incorporation of international experience in this field, which is not adequately covered in pedagogical studies and publications. In this context, in our opinion, the issue concerning the quality methodology of higher education remains relevant in the context of synergies of general scientific approaches: systemic and synergistic. The latter will lead to a deep understanding and study of the phenomenon of the quality of education as a systemic phenomenon, for which multivariance, multidimensionality and openness, the presence of nonlinear constraints and bifurcations of states are characteristic features. This approach will lead to a different vision of modern realities, the introduction of basic quality principles in the national education sphere, the development of criteria, methodology and technology for assessing the quality of education and its expert support.

\section{THE NOTION OF “QUALITY EDUCATION” AS A SYSTEM OBJECT}

The category "quality of education" is multifaceted and in its essence reflects various aspects of the educational process: philosophical, social, pedagogical, political, demographic, economic, etc. Therefore, for our study, the validation of 
the quality of education not only as a pedagogical, but also philosophical, social economic and sociological category and in general as a system.

The results of scientific research (Sysoeva, \& Sokolova, 2010, p. 307) give grounds to assert that the concept of "quality of education" is motivated by the basic "quality", which has a prominent place in the system of philosophical categories and which has a large methodological and ideological significance both for the process of cognition and for solving a significant range of practical problems.

Analysing the evolution of the doctrine of quality, it is worth noting that it was created on a philosophical and methodological basis and developed from the quiltativeness of Aristotle to the modern qualitative paradigm (Subetto O. I.). Modern philosophy uses several interpretations of quality, from simple "quality is a constant set of properties of an object" (Frolov, and others, 1989) to a more general one: "quality is the essence of an object (phenomenon, process) that characterizes it as a given an object possessing a set of properties and belongs to a class of objects of the same type with it" (Frolov, and others, 1989). At the same time, in the same source, we find the definition of quality as a holistic integral characteristic of an object (the unity of its properties) in the system of its connections and relations with other objects.

In this interpretation, each subject in cooperation with others can be regarded as a system, and the quality that characterizes the subject as a system, by systemic quality (Philosophical Dictionary, 1966). Qualitative interpretation of the subject as a system, respectively, can be characterized by composition, structure, certain elements of the system and functional properties. The latter indicates the systemic nature of the category "quality" and its close meaningful connection with the main provisions of the system approach.

From the philosophical point of view, the quality of education is a generalizing sign of the problems of the development of education in the state and at the same time, it is an indicator of the conformity of educational policy and education reforms to personal and social needs. It is viewed both as a philosophical category and as a pedagogical problem (Lyashenko, 2011, p. 7). As a system object, it is characterized by the quality of goals, the quality of pedagogical progress and the quality of the result.

The systemic nature of this concept is indicated by yet another interpretation proposed by M. V. Kisil, in which the quality of education is a number of system-social qualities and characteristics that determine the conformity of the education system to accepted requirements, social norms, state educational standards. As the quality system of education, the author understands the totality of the organizational structure, methodologies, processes and resources necessary for the implementation of quality management (Kisil, 2005, p. 86).

Appropriate for our scientific researches is the interpretation of the phenomenon of the quality of education by the experts of the International Renaissance Foundation, who conducted an analytical study of the reform of the national educational policy. The quality of education is defined by them as a complex system, as a philosophical or moral concept, as a characteristic of a certain educational product, as a characteristic of education as a process from the point of view of the subjects of this process, which is the sphere of their professional activity (Bulakh, Voronenko, Kuznetsov and others, 2001).

Systematic study of the quality of education, according to Ya. K. Yakhnin, provides for the study of a set of problems that cover: a) finding out the essence 
of the basic concepts of the quality of education (its definitions, structural components, properties, criteria and norms, etc.); b) definition of procedures and indicators for assessing the quality of education (as an educational process, its result and functional system); c) monitoring and making managerial decisions to ensure the established quality standards of education at all levels (Yakhnin, 2006, p. 16).

\section{QUALITY OF EDUCATION AS A SYNERGETIC CATEGORY}

As we know, even before the emergence of synergetics in scientific research, researchers could do without the use of a systematic approach to their objects without taking into account the collective effects that lead to the formation of stable structures in time and space. Now a consistent study of these problems has become possible thanks to a synergetic approach, with the emergence of which, new areas of research in the field of education have appeared, for example, pedagogical synergetics. It is pedagogical synergetics, as V. Kremen notes, makes it possible to take a new approach to the development of the problems of the development of pedagogical systems and the pedagogical process, first of all, from the standpoint of openness, co-creation and orientation toward self-development (Kremen, 2013, 3-4). Therefore, it is from the position of synergetics that qualitatively "in a new way" one can approach the study of the concept of "quality of education".

From the indicated positions, the following important components of the use of the ideas of the synergetic theory in the investigated problem can be singled out: their use in modelling and forecasting the development of the quality of education as a process, managing it and promoting the effectiveness of the functioning of the entire educational system as a whole.

First of all, let's go to the study of the concept of "quality" as an open system education, because openness is one of the most important characteristics of system objects. Openness, from the point of view of synergetics, means the use of the system of all opportunities and information flows related to environmental conditions, the definition of the most significant external conditions, factors that contribute to or impede the functioning of the system.

As a philosophical category, "quality" expresses the essential certainty of an object, through which it is precisely this, and not the other. On the other hand, the philosophical aspect of the category of "quality" shows the corresponding level of human cognition of objective reality. At each stage of cognition, certain properties of the object are revealed. That is, the environment affects the object, as a result of which it changes, and, consequently, its quality also changes. On this phenomenon, in our opinion, it is possible to trace the openness of the category of "quality", as a system that flexibly reacts to external changes.

Given this, with synergistic positions, one can approach the interpretation of the quality of education. Despite the fact that O. I. Korsak, that high-quality secondary and high school can seem semi-closed entities, concentrated on daily practical matters, in fact, they are a composite of an excellent all-planetary system of billions of inhabitants of hundreds of countries (Korsak, 2017, p. 73). Let's add to the above that the education system is an open system, then the quality of education in turn can be considered as an open system. Thus, in particular, openness indicates such a meaningful aspect of the quality of higher education as its compliance with the expectations of society, formalized in state standards, as well as the influence of the professional environment and the labour market. Thus, S. Ye. Shyshov and 
V. A. Kalney understand the quality of education as "a social category that studies the state and effectiveness of the education process in society, its relevance to the needs and expectations of society" (Shyshov, \& Kalney, 2000, p. 9).

The failure to comply with this norm leads to the fact that the problem of the quality of education is reduced to a contradiction between the current needs of production, the economy and society and the education system, does not always and not in all correspond to these needs. As Ye. M. Korotkov notes in this regard, the quality of education in this case allows to set and solve those development goals that are necessary for modern society (Korotkov, 2004, p. 59).

On the content of the concept of "quality of education" and its correspondence to the needs of the individual, society and the state, T. O. Lukina stresses. Moreover, omnitude now makes it an object of the study not only for pedagogy, but also for many other sciences (first of all, philosophy, sociology of economics, political science, psychology, management theory, etc.). We note in passing that with the onset of the new century this list was replenished with cognitology, neuromolecular biology, etc. (Lukina, 2008, p.1017-1018).

Naturally, with each of these areas of knowledge, the quality of education is a separate industry, united by close ties, which are sometimes non-linear. In such interrelations, we find advantages in the development of the quality of education as an interdisciplinary direction of research, when in fact the development of the pedagogical, philosophical, economic and other branches induce new non-linear links in the investigated field and the production of new knowledge.

\section{THE QUALITY OF HIGHER EDUCATION AND ITS EXPERT SUPPORT IN THE CONTEXT OF GENERAL SCIENTIFIC APPROACHES: MODERN DIMENSIONS}

Turning to those historical moments, namely, in 2005, when Ukraine joined the Bologna Process, we can recall the elevated mood of teachers and all non-indifferent Ukrainians towards the future of national education. Since then, more than ten years have passed. Is the Ukrainian community happy with its higher education, competitiveness in the labour market of our graduates? Analysing the priorities of our youth in favour of foreign higher educational institutions and not the best positions of Ukrainian universities in world academic rankings, we can give a negative answer.

The quality of domestic education, which is one of the main requirements of the Bologna Declaration, does not satisfy young people, their parents, or employers. It should be noted that the quality of higher education is the main requirement that ensures the responsibility of universities, trust in it, the conformity of the labour market, mobility and compatibility of qualifications. In addition, the qualitative training of specialists allows them to be competitive at the international level (Sikorsky, 2016, p. 54).

From the above theoretical and methodological positions, modern achievements in the quality of education and its expert support are analysed.

Let us note that along with other countries of the European Community, Ukraine has embarked on the path of developing common approaches to the quality of education common to all countries. On March 4, 2008 in Brussels (Belgium), Ukraine was accepted by the authorized government member of the European Quality Assurance Register (EQAR). The government members of this register are 18 countries participating in the Bologna Process. This fact has become 
an extremely important achievement of the Ministry of Education and Science of Ukraine in the direction of ensuring the quality of higher education at the European level.

In the updated law of Ukraine "On Higher Education", the concept of the quality of education is interpreted as the "level" of knowledge, skills, competences obtained by the person, reflecting its competence in accordance with higher education standards (Law of Ukraine "On Higher Education", Article 1). Let's notice, that in scientific circles discussions on correctness of the formulated concept are topical till now.

In one of the points of Article 16 of the Law it is stated that the system of quality assurance of educational activities of higher education institutions and the quality of higher education provides for the implementation of such procedures and activities as, for example, "ensuring the availability of promulgated decision criteria in accordance with standards and quality recommendations in the European space higher education", as well as in paragraph 2 of Article 23, it is emphasized: "Independent institutions for evaluation and quality assurance of higher education to cooperate with the European Association and the quality of higher education, with the aim of introducing European standards and recommendations to improve the quality of higher education in Ukraine" (The Law of Ukraine "On Higher Education", 2014, Articles 16, 23).

Despite the positive developments at the legislative level, the realities of the current development of higher education in Ukraine testify to its closed nature: quality requirements are formulated and verified by mainly profile ministries (executors, not real customers of educational services) that do not always correlate with the real needs of the open market. At the same time important players who should turn the participants into the educational process - business, students, national and international public organizations and others - do not participate (even indirectly) in quality assurance procedures, although formally such participation is envisaged. The main task of educational institutions is not to improve one's own quality and efficiency, but the success of formal reporting to state control bodies (the Concept of Quality Assurance in Higher Education, 2014).

The closed nature of the higher education system in Ukraine encourages the following: the process of ensuring the quality of education remains closed and does not meet the demands of the society. The main differences in the formation of the Ukrainian system for ensuring the quality of higher education and the European one, which can be called an open nonlinear system, are given in Table 1.

Table 1

The main differences in the formation of Ukrainian and European higher education quality assurance systems

\begin{tabular}{|l|l|}
\hline \multicolumn{1}{|c|}{ Open system (in the EU) } & \multicolumn{1}{|c|}{ Closed system (in Ukraine) } \\
\hline $\begin{array}{l}\text { Development conditions: freedom of } \\
\text { choice in market conditions }\end{array}$ & $\begin{array}{l}\text { Development conditions: administrative- } \\
\text { command system }\end{array}$ \\
$\begin{array}{l}\text { Primary consumer of education: student, } \\
\text { employer }\end{array}$ & $\begin{array}{l}\text { Primary consumer of education: the } \\
\text { state mechanism }\end{array}$ \\
$\begin{array}{l}\text { The accumulation of skills and abilities } \\
\text { by the society in setting requirements } \\
\text { for the quality of education }\end{array}$ & $\begin{array}{l}\text { Skills and abilities to adapt to the } \\
\text { demands of the authorities }\end{array}$ \\
\hline
\end{tabular}

(Based on the materials of the "Concept of quality assurance of higher education in Ukraine. The project "TRUST"). 
These differences in the quality of higher education in the EU and Ukraine and the closed nature of the formation of the Ukrainian system for quality assurance of higher education make it impossible, in our view, to develop the European vector of the national higher school as a whole.

The latter, in our opinion, is strengthened by the lack of clearly defined powers and the role of expertise in education as an area of scientific and practical activity, actively developing in the countries of the West. The European educational space has already developed a ramified hierarchical system of expert support for projects, in particular in the field of education. In fact, no educational innovation does not bypass expert appraisal at various stages of its implementation and implementation. Expert communities are active in professional environments, in which experts are trained, urgent scientific problems of expertise are discussed.

So, in order to make education "work" for the contemporary needs of society it must develop as an open system, and its content and technologies should contribute to the education of people capable of developing their potential for a free and creative person throughout their lives and ensuring the stable functioning of society (Batechko, \& Sysoyeva, 2011, p. 312).

The contradiction between the proclaimed European vectors for the development of the quality of higher education and the real state of affairs in this field in Ukraine prompt both a deeper theoretical analysis and the practical introduction of the best Western models. However, the opinion of V. S. Lutay will be to the point here: "We must not mechanically borrow foreign models of development, but develop our own - specific for Ukraine." (Lutay Vladlen, 2005, p. 51). Indeed, the mere copying of Western models of introducing quality education is unlikely to succeed in Ukrainian high school. Therefore, all ratings and indicators of the quality of education systems must be taken analytically, taking into account their nature, and, most importantly, not making political generalizations based on them (like "the best education system in the world in Finland") (O. I. Lyashenko, O. Lukina, L. S. Vashchenko, and others). In our opinion, taking into account the best European practices in ensuring the quality of education and our own vision of the problem, taking into account the historical roots of the national education sphere, the Ukrainian mentality, and our own scientific approaches, we will accelerate the reform processes of Ukraine's higher school and its European vector of development.

\section{CONCLUSIONS}

In the process of research, we came to the conclusion that the interpretation of the essence of "quality of higher education" is different. This situation leads to problems in understanding the conceptual and terminological apparatus, which, in our opinion, complicates the process of introducing the quality of education, in particular, in higher education. Increasingly, in recent years there has been an attempt to resolve them solely by pedagogical means, which, as a rule, do not bring the desired result. The problem under investigation cannot be solved only within the framework of pedagogical theory and educational practice. The theoretical and methodological justification of the "quality of education" from the standpoint of the synergy of general scientific approaches: systemic and synergistic approaches, in our view, positions the quality of higher education as an open, non-linear system capable of self-development. Such an interpretation of the investigated 
phenomenon will allow, in our opinion, to develop evolutionary models for the development of the quality system of the national higher education, relieve its isolation and will support the substantiation of the basic principles of expert support for it.

Further research suggests the conducting of a narrowly focused study as for the justification of general scientific approaches to the management of the quality of education.

\section{REFERENCES}

Batechko, N. (2017). Quality management in higher education sphere: methodological aspect. Osvitolohiya, 6, 156-162, doi: 10.28925/2226-3012.2017.6.156162

Bulakh, I., Voronenko, Yu., \& Kuznetsova, V. (n.d.). Monitoring system and education quality assessment: An analytical study on reforming the national educational policy / and others. Retrieved from http: //www.irf.kiev.ua

Frolov, E., Arai-Ogly, E., \& Arefyeva, G. (1989). Introduction to Philosophy: a manual for higher educational establishments in 2 parts, Part 2.

Kisil, M. (2009). Assessment of the quality of higher education, Higher Education of Ukraine, 14, 82-87.

Lukina, T. (2008). Quality of Education. Encyclopedia of Education. Kyiv, Ukraine, 1017-1018.

Organizational and methodological support of monitoring studies of the quality of general secondary education: monograph (2011). O. Lyashenko (Ed.), Pedagogichna Dumka (Pedagogical Thought). Kyiv, Ukraine.

Philosophical Dictionary (1986). V. Shynkaruk (Ed.), Kyiv, Ukraine.

Shchogoleva, L. (2014). Monitoring of the Education Quality: Theoretical and Methodological Aspect. Pedagogical process, 2, 3640.

Sysoyeva, S. (2010). Problems of Continuing Professional Education. The Thesaurus of Scientific Research: Scientific edition, Kyiv, Ukraine, 362.

The Law of Ukraine "On Higher Education" (2014). Retrieved from http: // kodeksy / com.ua / proosvity / statja - 1.htm.

Trygub, I. (2014). Expert evaluation as a component of professional activity in the field of education: theoretical aspect. Osvitoligichnyi dyskurks (Educational discourse), 1 (5), 218-225.

Volkov, O. (2006). Quality systems of higher educational institutions: theory and practice. Naukova Dumka (Scientific thought), 301.

Contents of the article reflects only the author's view, the Agency and the Commission are not responsible for any use that may be made of the information it contains. 